\title{
PENERAPAN MODEL PEMBELAJARAN KOOPERATIF STUDENT TEAM ACHIEVEMENT DIVISION (STAD) UNTUK MENINGKATKAN PRESTASI BELAJAR PKn
}

\author{
Oleh: \\ Ida Bagus Putu Sudiarta
}

\begin{abstract}
Abstrak
Pencapaian prestasi belajar PKn siswa VI Semester I SD Negeri 2 Ubung Tahun Pelajaran 2016/2017 berada di bawah tuntutan KKM sebesar 75 poin. Sesuai hasil observasi yang telah dilakukan, rendahnya prestasi yang diperoleh siswa disebabkan oleh rendahnya kecakapan sosial siswa. Ketika siswa diminta mengerjakan tugas secara individu, siswa tidak merasakan kesulitan berarti meskipun nilai yang diperolehnya tergolong pas-pasan. Namun ketika siswa diminta mengerjakan tugas secara berkelompok, banyak siswa yang hanya membebankan tugas pada siswa yang dianggap pintar saja, dan siswa yang pintar tersebut cenderung asal-asalan dalam bekerja karena merasa tidak dibantu oleh teman sekelompoknya. Hal ini sangat berdampak buruk kepada nilai prestasi belajar siswa. Berdasarkan pengetahuan dan pemahaman peneliti, untuk menanggulangi permasalahan yang terjadi, peneliti perlu melakukan penelitian tindakan kelas dengan menenerapkanModel Pembelajaran Kooperatif Student Team Achievement Division (STAD). Model pembelajaran ini didesign untuk tim kecil yang berjumlah 4-5 orang yang masing-masing tim itu bisadiatur tingkat kemampuan siswanya maupun gendernya. Guru menyajikan pelajaran,kemudian siswa bekerja bertim dan memastikan agar masing-masing individu dalamtim dapat pekerjaan yang dikerjakan dan masing-masing tim meyakinkan dirinya agaranggotanya dapat menguasai pelajaran yang diberikan oleh gurunya. Penelitian ini dilakukan dalam dua tahap yakni siklus I dan siklus II.Pengumpulan data menggunakan tes prestasi belajar.Teknik analisis data berupa analisis deskriptif kuantitatif.Sesuai hasil penelitian menunjukkan bahwa penggunaan model Pembelajaran Kooperatif Student team achievement division (STAD).pada mata pelajaran PKn telah membuat prestasi siswa meningkat. Hal ini tercermin dari nilai rata-rata pada data awal sebesar 61,85 pada siklus I rata-rata nilai meningkat menjadi 71,48. Pada siklus II prestasi belajar siswa juga mengalami peningkatan menjadi 82,78. Ketuntasan belajar siswa juga mengalami peningkatan pada awalnya hanya6 siswa(22,22\%)menjadi 15 siswa(55,56\%)pada siklus I dan pada siklus II ketuntasan juga mengalami peningkatan menjadi 25 siswa(92,59\%). Saran yang diajukan berdasarkan hasil penelitian yaitu Model Pembelajaran Kooperatif Student team achievement division (STAD) dapat digunakan sebagai alternatif untuk meningkatkan prestasi belajar siswa pada mata pelajaran PKn.
\end{abstract}

Kata kunci : student team achievement division(stad),prestasi belajar 


\section{Pendahuluan}

Pendidikan nasional bertujuan untuk mengembangkan potensi siswa agar menjadi manusia yang beriman dan bertakwa kepada Tuhan Yang Maha Esa, berakhlak mulia, sehat, berilmu, cakap, kreatif, mandiri, dan menjadi warga negara yang demokratis serta bertanggung jawab. Untuk dapat mencapai tujuan pendidikan nasional, pendidikan seyogyanya dilakukan sedini mungkin. Salah satu tujuan pendidikan nasional yakni membentuk warga negara yang demokratis serta bertanggung jawab. Untuk dapat mencapai tujuan tersebut, dibutuhkan mata pelajaran yang tepat. Oleh karena itu, pendidikan di Sekolah Dasar diharuskan mengajarkan 10 mata pelajaran, dan salah satunya adalah Pendidikan Kewarganegaraan. Pengertian Pendidikan Kewarganegaraan menurut Peraturan Menteri Pendidikan No. 22 tahun 2006 adalah "suatu mata pelajaran yang memfokuskan pada pembentukan warga negara yang memahami dan mampu melaksanakan hak-hak dan kewajibannya untuk menjadi warga negara Indonesia yang cerdas, terampil dan berkarakter yang diamanatkan oleh Pancasila dan UUD 1945" (dalam Wuri Wuryandani, 2011: 7).Sedangkan tujuan Pendidikan Kewarganegaraan menurut Wuri Wuryandani (2011: 7) yakni: (1) berpikir secara kritis, rasional dan kreatif dalam menanggapi isu kewarganegaraan, (2) berpartisipasi secara aktif dan bertanggung jawab dan bertindak secara cerdas dalam kegiatan bermasyarakat, berbangsa dan bernegara serta anti korupsi, (3) berkembang secara positif dan demokratis untuk membentuk diri berdasarkan karakter-karakter masyarakat Indonesia agar dapat hidup bersama dengan bangsa-bangsa lainnya, (4) berinteraksi dengan bangsabangsa lain dalam percaturan dunia secara langsung atau tidak langsung dengan memanfaatkan teknologi informasi dan komunikasi.

Secara garis besar dapat diketahui bahwa pendidikan kewarganegaraan merupakan pembelajaran yang penting. Meskipun demikian, sering kali pendidikan kewarganegaraan menjadi mata pelajaran yang kurang diminati oleh siswa. Dengan rendahnya minat tersebut tentu saja menyebabkan rendahnya prestasi belajar PKn siswa. Hal tersebut terjadi di SD Negeri 2 Ubung, tepatnya pada siswa kelas VI semester I tahun pelajaran 2016/2017.

Sesuai hasil observasi yang telah dilakukan, rendahnya prestasi yang diperoleh siswa disebabkan oleh rendahnya kecakapan sosial siswa. Ketika siswa diminta mengerjakan tugas secara individu, siswa tidak merasakan kesulitan berarti meskipun nilai yang diperolehnya tergolong paspasan. Namun ketika siswa diminta mengejakan tugas secara berkelompok, banyak siswa yang hanya membebankan tugas pada siswa yang dianggap pintar saja, dan siswa yang pintar tersebut cenderung asal-asalan dalam bekerja karena merasa tidak dibantu oleh teman sekelompoknya. Hal ini sangat berdampak buruk kepada nilai prestasi belajar siswa.

Berdasarkan pengetahuan dan pemahaman peneliti, untuk menanggulangi permasalahan yang terjadi, peneliti perlu melakukan 
penelitian tindakan kelas dengan cara menenerapkanModel Pembelajaran Kooperatif Student Team Achievement Division (STAD) untuk Meningkatkan Prestasi Belajar PKn Siswa Kelas VI Semester I SD Negeri 2 Ubung Tahun Pelajaran 2016/2017.

Berdasarkan latar belakang di atas, masalah dalam penelitian ini dapat dirumuskan sebagai berikut :Apakah Penerapan Model Pembelajaran Kooperatif Student Team Achievement Division (STAD) dapat Meningkatkan Prestasi Belajar PKn pada Siswa Kelas VI Semester I SD Negeri 2 Ubung Tahun Pelajaran 2016/2017?

Berdasarkan permasalahan diatas, tujuan penelitian tindakan kelas ini adalah: Untuk Meningkatkan Prestasi Belajar PKn pada Siswa Kelas VI Semester I SD Negeri 2 Ubung Tahun Pelajaran 2016/2017 melalui Penerapan Model Pembelajaran Kooperatif Student Team Achievement Division (STAD).

Manfaat yang ingin diperoleh dari penelitian ini adalah sebagai berikut, 1) Bagi Siswa, Meningkatkan Aktivitas dan Prestasi siswa dalam pembelajaran PKn, Meningkatkan kemampuan siswa dalam mengemukakan pendapat, Meningkatkan kemampuan bekerja sama siswa dalam belajar tim, Memberikan suasana belajar yang lebih menarik dan kondusif dalam pembelajaran. 2) Bagi guru, Sebagai acuan dalam upaya mempertimbangkan penggunaan model Pembelajaran Kooperatif
Student Team Achievement Division (STAD) untuk meningkatkan prestasi belajar siswa, Sebagai motivasi guruguru yang lain agar melaksanakan penelitian tindakan kelas pada tiap-tiap mata pelajaran, sebagai upaya menemukan inovasi baru dalam kegiatan pembelajaran, Sebagai acuan bagi guru-guru yang ingin melaksanakan penelitian tindakan kelas (classroom action research). 3) Bagi sekolah, Meningkatkan mutu pendidikan secara umum, sekaligus meningkatkan mutu sekolah, Hasil penelitian ini dapat dijadikan awal dari pembaharuan dalam kegiatan pembelajaran di SD Negeri 2 Ubung. Model Pembelajaran Kooperatif Student Team Achievement Division (STAD), didesign untuk tim kecil yang berjumlah 4-5 orang yang masingmasing tim itu bisadiatur tingkat kemampuan siswanya maupun gendernya.Guru menyajikan pelajaran,kemudian siswa bekerja bertim dan memastikan agar masingmasing individu dalamtim dapat pekerjaan yang dikerjakan dan masingmasing tim meyakinkan dirinya agaranggotanya dapat menguasai pelajaran yang diberikan oleh gurunya. Ada lima komponen utama dalam STAD yaitu: presentasi kelas, tim, kuis,perbaikan skor individu, dan pengenalan tim (Salvin, 1995). Ni Luh Rasmini (2010: 23-24) menulis bahwa sintak STAD seperti terlihat pada tabel berikut. 
Tabel 01. Sintak Pembelajaran Kooperatif Students Team Achievement Division (STAD)

\begin{tabular}{|l|l|l|}
\hline \multicolumn{1}{|c|}{ Fase } & Kegiatan Guru & Kegiatan Siswa \\
\hline $\begin{array}{l}\text { Fase 1. } \\
\text { Menyampaikan tujuan dan } \\
\text { memotivasi siswa }\end{array}$ & $\begin{array}{l}\text { Mengupayakan semua tujuan pembelajaran } \\
\text { yang ingin dicapai pada pelajaran tersebut dan } \\
\text { memotivasi siswa belajar }\end{array}$ & $\begin{array}{l}\text { Siswa mendengarkan } \\
\text { penjelasan guru }\end{array}$ \\
\hline $\begin{array}{l}\text { Fase 2. } \\
\text { Menyajikan/ menyampaikan } \\
\text { informasi }\end{array}$ & $\begin{array}{l}\text { Menyajikan informasi kepada siswa dengan } \\
\text { jalan mendemonstrasikan atau lewat bahan } \\
\text { bacaan }\end{array}$ & $\begin{array}{l}\text { Siswa mendengarkan } \\
\text { kemudian mencatat } \\
\text { penjelasan guru }\end{array}$ \\
\hline $\begin{array}{l}\text { Fase 3. } \\
\text { Mengorganisasikan siswa } \\
\text { dalam kelompok-kelompok } \\
\text { belajar }\end{array}$ & $\begin{array}{l}\text { Menjelaskan pada siswa bagaimana caranya } \\
\text { membentuk kelompok belajar dan membantu } \\
\text { seiap kelompok agar melakukan transisi } \\
\text { secara efesien }\end{array}$ & $\begin{array}{l}\text { Siswa membentuk } \\
\text { kelompok sesuai arahan } \\
\text { guru }\end{array}$ \\
\hline $\begin{array}{l}\text { Fase 4. } \\
\text { Membimbing kelompok } \\
\text { belajar }\end{array}$ & $\begin{array}{l}\text { Membimbing kelompok- kelompok belajar } \\
\text { pada saat mereka mengerjakan tugas mereka }\end{array}$ & $\begin{array}{l}\text { Siswa berdiskusi tentang } \\
\text { materi yang diberikan }\end{array}$ \\
\hline $\begin{array}{l}\text { Fase 5. } \\
\text { Evaluasi }\end{array}$ & $\begin{array}{l}\text { Mengevaluasi hasil belajar tentang materi } \\
\text { yang telah diajarkan atau masing-masing } \\
\text { kelompok mempresentasikan hasil kerjanya }\end{array}$ & $\begin{array}{l}\text { Siswa mendengarkan } \\
\text { klarifikasi jawaban antar } \\
\text { kelompok }\end{array}$ \\
\hline $\begin{array}{l}\text { Fase 6. } \\
\text { Memberikan penghargaan }\end{array}$ & $\begin{array}{l}\text { Mencari cara-cara untuk menghargai baik } \\
\text { upaya maupun hasil belajar individu dan } \\
\text { kelompok }\end{array}$ & $\begin{array}{l}\text { Siswa dari kelompok lain } \\
\text { memberikan aplaus untuk } \\
\text { kelompok yang terbaik }\end{array}$ \\
\hline
\end{tabular}

Pembelajaran kooperatif tipe STAD mempunyai beberapa keuntungan dan kelamahan. Slavin (1995)menyebutkan beberapa keuntungan dan kelemahan dari pembelajaran kooperatif tipe STAD. Beberapa keuntungannya antara lain: (1) Setiap anggota kelompok mendapat tugas; (2) Adanya interaksi langsung antar siswa dalam kelompok; (3) Melatih siswa mengembangkan keterampilan sosial (social skill), (4) Membiasakan siswa menghargai pendapat orang lain, (5) Meningkatkan kemampuan siswa dalam berbicara dan berbuat, sehingga kemampuan akademiknya meningkat, (6) Memberi peluang kepada siswa untuk berani bertanya dan mengutarakan pendapat, (7) Memfasilitasi terwujudnya rasa persaudaraan dan kesetiakawanan, (8)
Terlaksananya pembelajaan yang berpusat pada siswa, sehingga waktu yang tersedia hampir seluruhnya digunakan oleh siswa untuk kegiatan pembelajaran, dan (9) Memberi peluang munculnya sikap-sikap positif siswa

Adapaun beberapa kelemahan dari pembelajaran kooperatif tipe STAD adalah, (1) Dalam pelaksanaan di kelas, membutuhkan wakru yang relatif lebih lama sehingga sulit mencapai target kurikulum; (2) Dalam mempersiapkannya guru membutuhkan waktu yang lama; (3) Membutuhkan kemampuan khusus guru, sehingga tidak semua guru dapat melakukan dan menggunakan strategi belajar kooperatif, (4) Menuntut sifat tertentu tertentu dari siswa, misalnya sifat suka bekerja sama. 
Pada prinsipnya yang diungkapkan di atas bukan merupakan kekurangan tetapi merupakan kendala yang dihadapi dalam pembelajaran.

Sementara itu, terkait dengan prestasi belajar, Sumadi Suryabrata (2006: 297), mendefinisikan prestasi sebagai berikut, "nilai merupakan perumusan terakhir yang dapat diberikan oleh guru mengenai kemajuan/prestasi belajar siswa selama masa tertentu". Jadi, prestasi adalah hasil usaha siswa selama masa tertentu melakukan kegiatan.

Berhasil dan tidaknya seseorang dalam belajar dipengaruhi oleh beberapa faktor. Faktor-faktor yang mempengaruhi pencapaian hasil belajar siswa adalah faktor internal dan faktor eksternal. Faktor internal, yaitu faktor yang berasal dari dalam diri siswa yang meliputi faktor fisiologis dan faktor psikologis. Sedangkan Faktor eksternal, yaitu faktor yang berasal dari luar diri siswa yang meliputi lingkungan fisik dan sosial serta instrumen yang berupa kurikulum, program, metode mengajar, guru, sarana dan fasilitas

Berdasarkan masalah yang ada dan solusi yag ditawarkan, dibuatlah hipotesis sebagai berikut, Jika langkahlangkah model Pembelajaran Kooperatif Students TeamAchievement Division (STAD) dapat diterapkan dengan baik dan benar, maka Prestasi Belajar PKn Siswa Kelas VI pada Semester I Tahun SD Negeri 2 Ubung Tahun Pelajaran 2016/2017 dapat meningkat.

\section{Metode Penelitian}

Tempat pelaksanaan penelitian ini adalah di SD Negeri 2 Ubungyang berlokasi di Jl. Irawan No 16 Ubung Kaja - Denpasar Utara Prosedur yang dilakukan peneliti untuk mengadakan penelitian demi memperoleh data yang lengkap dan sesuai adalah sebagai berikut.

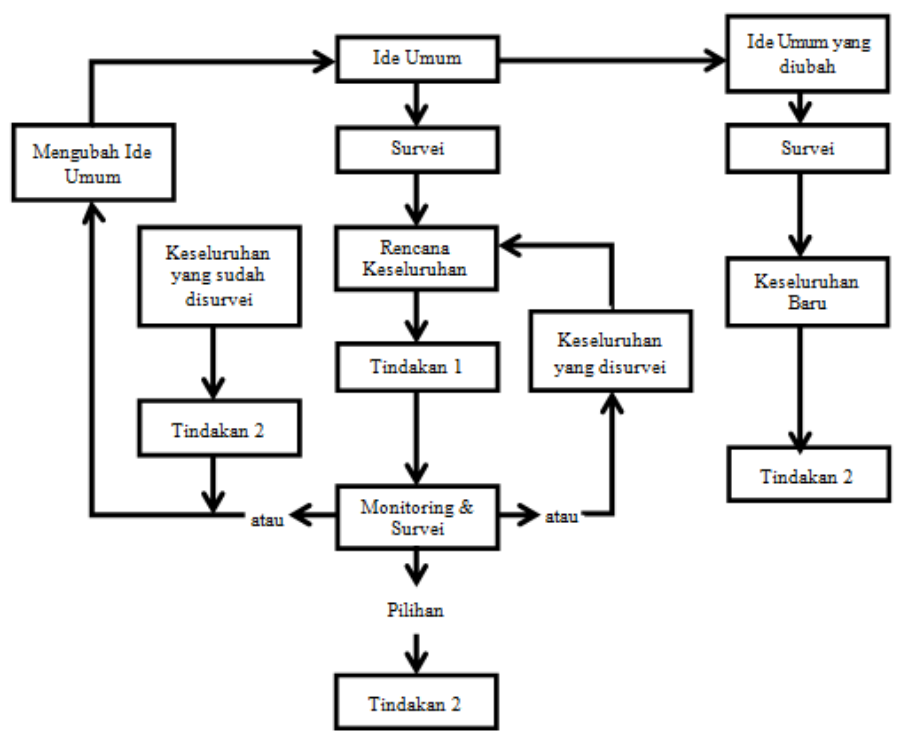


Gambar 01. Rancangan Penelitian Model Ebbut, 1985 (Basrowi \&Sukidin,2002)

Sesuai bagan di atas, diketahui bahwa penelitian dimulai dari membuat perencanaan awal, kemudian melakukan tindakan berdasarkan rencana sambil melakukan observasi, kemudian dilakukan refleksi, jika target belum tercapai maka dilakukan perbaikan perencanaan, dilakukan tindakan lagi sesuai rencana yang sudah diperbaiki, lalu direfleksi lagi dan begitu seterusnya.

Sebagai subjek pada penelitian ini adalah semua siswa kelas VI Semester I SD Negeri 2 Ubung Tahun Pelajaran 2016/2017.Objek penelitian ini adalah peningkatan prestasi belajar PKn Pada Siswa Kelas VI Semester I SD Negeri 2 Ubung tahun pelajaran 2016/2017 setelah diterapkan model Pembelajaran Kooperatif Student Team Achievement Division (STAD).Jadwal dari penelitian tindakan kelas ini dari bulan Juli sampai dengan bulan Nopember 2016Tahun Pelajaran2016/2017

Untuk mengumpulkan data digunakan metode tes prestasi belajar kepada siswa, kemudian untuk menganalisis data hasil penelitian menggunakan metode deskriptif. Untuk data kuantitatif dianalisis dengan mencari mean, median, modus, membuat interval kelas dan melakukan penyajian dalam bentuk tabel dan grafik.

Batas yang menentukan berakhirnya penelitian ini adalah apabila pada siklus tertentu tercapai rata-rata nilai siswa mencapai atau melampaui KKM sebesar 75 dengan

persentase ketuntasan belajar minimal $85 \%$

III. Hasil Penelitian dan Pembahasan

A. Hasil Penelitian

1. Deskripsi Awal

Pada kegiatan awal ini diperoleh hasil sebagai berikut, pada KKM sebesar 75 dengan jumlah siswa sebanyak27siswa di kelas tersebut, hanya terdapat6 siswa yang nilainya memenuhi KKM, atau ketuntasan yang berhasil diperoleh hanya sebesar22,22. Sedangkan 21 siswalainya memperoleh nilai dibawah KKM. Nilai rata-rata pada silkus awal ini adalah sebesar 61,85.Ketidakberhasilan tersebut dikarenakan rendahnya kecakapan sosial siswa. Ketika siswa diminta mengerjakan tugas secara individu, siswa tidak merasakan kesulitan berarti meskipun nilai yang diperolehnya tergolong paspasan. Namun ketika siswa diminta mengejakan tugas secara berkelompok, banyak siswa yang hanya membebankan tugas pada siswa yang dianggap pintar saja, dan siswa yang pintar tersebut cenderung asal-asalan dalam bekerja karena merasa tidak dibantu oleh teman sekelompoknya. Hal ini sangat 
berdampak buruk kepada nilai prestasi belajar siswa..

2. Deskripsi Siklus I

a. Rencana Tindakan I

1) Menyusun jadwal untuk pelaksanaan, 2)Menyusun rencana kegiatan. 3) Berkonsultasi dengan teman-teman guru, membicarakan alat-alat peraga, bahan-bahan yang bisa membantu peningkatan

perkembangan peserta didik. 4) Merencanakan model pembelajaran yang paling tepat diinginkan dalam pembelajaran. 5) Menyusun format penilaian. 6) Membuat bahan-bahan pendukung pembelajaran lainnya, 7)Merancang skenario pembelajaran

b. Pelaksanaan Tindakan I

1) Guru mengupayakan semua tujuan pembelajaran yang ingin dicapai pada pelajaran tersebut dan memotivasi siswa belajar, 2) Guru menyajikan informasi kepada siswa dengan jalan mendemonstrasikan atau lewat bahan bacaan,3) Guru menjelaskan pada siswa bagaimana caranya membentuk kelompok belajar dan membantu seiap kelompok agar melakukan transisi secara efesien,4) Guru membimbing kelompok- kelompok belajar pada saat mereka mengerjakan tugas mereka,5)

Guru mengevaluasi hasil belajar materi yang telah diajarkan atau masing-masing kelompok

mempresentasikan hasil kerjanya, 6) Terakhir, Guru mencari cara-cara untuk menghargai baik upaya maupun hasil belajar individu dan kelompok.

c. Observasi

1) Menilai tugas-tugas yang disuruh. 2) Mengobservasi kegiatan yang dilakukan anak-anak. 3) Menilai prestasi belajar mereka.

Hasilnyaadalah, dari total 27 siswa yang mengikuti pembelajaran $\quad \mathrm{PKn}$ menggunakan model Pembelajaran Kooperatif Student Team Achievement Division (STAD), terdapat 15 siswa yang sudah memperoleh nilai yang memenuhi KKM, sedangkan nilai 12 siswa lainnya masih belum dapat memenuhi KKM. Nilai rata-rata pada siklus ini adalah 71,48 dengan persentase ketuntasan belajar sebesar 55,56\%.

d. Refleksi

Berdasarkan data yang telah dikumpulkan, analisis kuantitatifnya sebagai berikut : 
1) Rata-rata (mean) : $\frac{\text { Jumlahnilai }}{\text { Jumlahsiswa }}=\quad \frac{1930 .}{27}=$ 72,48

2) Median yang diperoleh dari data siklus I adalah: 75

3) Modus yang diperoleh adalah80

4) Banyak kelas $(\mathrm{K})=1+3,3 \times \log$ (N)

$$
\begin{aligned}
& =1+3,3 \times \log 27 \\
& =1+3,3 \times 1,43 \\
& =1+4,72=5,72=6
\end{aligned}
$$

(dibulatkan)

5) Rentang kelas (r) =skor maksimum - skor minimum

$$
=90-45=45
$$

\begin{tabular}{|c|c|c|c|c|}
\hline $\begin{array}{l}\text { No } \\
\text { Urut }\end{array}$ & Interval & $\begin{array}{c}\text { Nilai } \\
\text { Tengah }\end{array}$ & $\begin{array}{c}\text { Frekuensi } \\
\text { Absolut }\end{array}$ & $\begin{array}{c}\text { Frekuensi } \\
\text { Relatif }\end{array}$ \\
\hline 1 & $45-52$ & 48,5 & 5 & $18,52 \%$ \\
\hline 2 & $53-60$ & 56,5 & 3 & $11,11 \%$ \\
\hline 3 & $61-68$ & 64,5 & 1 & $3,70 \%$ \\
\hline 4 & $69-76$ & 72,5 & 6 & $22,22 \%$ \\
\hline 5 & $77-84$ & 80,5 & 5 & $18,52 \%$ \\
\hline 6 & $85-92$ & 88,5 & 7 & $25,93 \%$ \\
\hline \multicolumn{3}{|c|}{ Total } & 27 & $100,00 \%$ \\
\hline
\end{tabular}

6) Panjang kelas interval (i) $=\frac{r}{K}=$ $\frac{45}{6}=7,50=8($ dibulatkan $)$

Tabel 02. Data Kelas Interval Siklus I

1) Penyajian dalam bentuk grafik/histogram

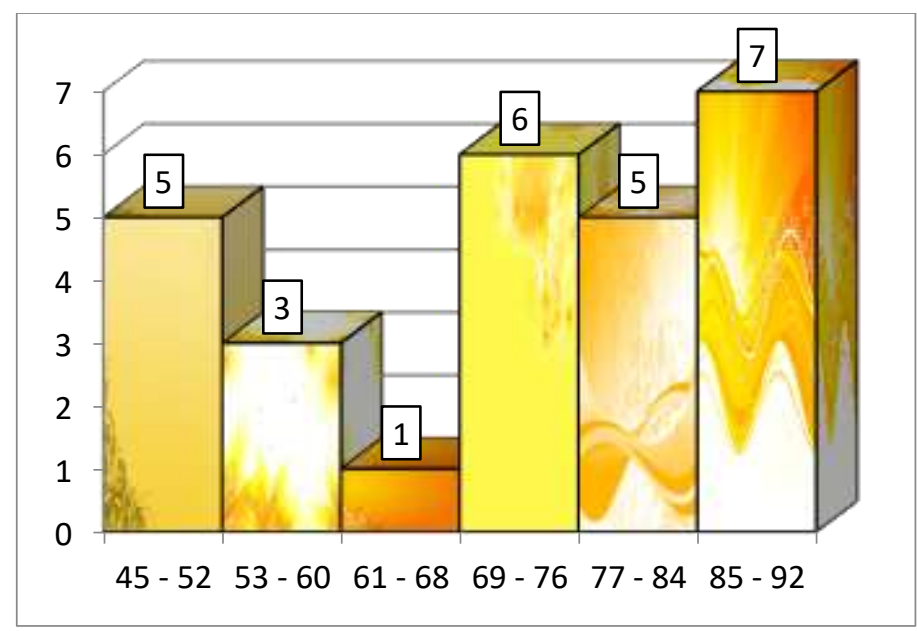

Gambar 02. Histogram Prestasi BelajarPKn Pada Siswa Kelas VI Semester I SD Negeri 2 Ubung Tahun Pelajaran 2016/2017 setelah diterapkan Model 


\section{Pembelajaran Kooperatif Student Team Achievement Division (STAD) Siklus I}

Setelah dilakukan refleksi dan penilaian, pada siklus I terdapat beberapa kekurangan yakni, 1) pembelajaran menggunakan model ini membutuhkan waktu yang relatif lama, 2) guru belum mampu menjadi fasilitator, mediator, motivator dan evaluator dengan baik

3. Deskripsi Siklus II

a. Rencana Tindakan II

Semua kelemahan yang sudah dipaparkan pada siklus I merupakan acuan untuk membuat perencanaan pada siklus II ini. Rencana pelaksanaan pembelajaran (RPP) disusun ulang, diberi penekanan pada beberapa hal yaitu: 1) meminimalisir penggunaan waktu dengan menyediakan lembar kegiatan siswa (LKS) sehingga siswa dapat bekerja secara efektif dan efisien, 2) meningkatkan mutu guru oleh pemerintah seperti mengadakan

kegiatan-kegiatan

akademik yang bersifat wajib dan tidak membebankan biaya kepada guru serta melakukan pengawasan rutin secara insindental, 3)pembentukan kelompok dan penataan ruang kelas sesuai kelompok yang ada dilakukan sebelum kegiatan pembelajaran dilaksanakan.

Pada perencanaan Siklus II ini ada banyak hal yang telah dilaksanakan yaitu, 1) Menyusun jadwal untuk pelaksanaan, 2)Menyusun rencana kegiatan. 3) Berkonsultasi dengan teman-teman guru, membicarakan alat-alat peraga, bahan-bahan yang bisa membantu peningkatan perkembangan peserta didik. 4) Merencanakan model pembelajaran yang paling tepat diinginkan dalam pembelajaran. 5) Menyusun format penilaian. 6) Membuat bahan-bahan pendukung pembelajaran lainnya, 7)Merancang skenario pembelajaran

b. Pelaksanaan Tindakan II 1) Guru mengupayakan semua tujuan pembelajaran yang ingin dicapai pada pelajaran tersebut dan memotivasi siswa belajar, 2) Guru menyajikan informasi kepada siswa dengan jalan mendemonstrasikan atau lewat bahan bacaan, 3) 
Guru menjelaskan pada siswa bagaimana caranya membentuk kelompok belajar dan membantu seiap kelompok agar melakukan transisi secara efesien,4) Guru membimbing kelompokkelompok belajar pada saat mereka mengerjakan tugas mereka, 5) Guru mengevaluasi hasil belajar materi yang telah diajarkan atau masing-masing kelompok mempresentasikan hasil kerjanya, 6) Terakhir, Guru mencari cara-cara untuk menghargai baik upaya maupun hasil belajar individu dan kelompok.

c. Observasi

Observasi/pengamatan/pen gumpulan data dilaksanakan dengan :1) Menilai tugas-tugas yang disuruh. 2) Mengobservasi kegiatan yang dilakukan anak-anak. 3) Menilai prestasi belajar mereka siklus II jumlah siswa yang nilainya memenuhi KKM bertambah menjadi 25 siswa, sedangkan siswa yang masih belum dapat memenuhi KKM hanya tersisa 2 siswa saja. Nilai rata-rata pada siklus ini adalah 82,78 dengan persentase ketuntasan belajar sebesar $92,59 \%$

d. Refleksi

Berdasarkan data yang telah dikumpulkan, Selanjutnya diberikan analisis kuantitatifnya mengingat data yang diperoleh adalah dalam bentuk angka sebagai berikut :

1) Rata-rata (mean) : $\frac{\text { Jumlahnilai }}{\text { Jumlahsiswa }}=$ $\frac{2235}{27}=82,78$

2) Median yang diperoleh dari data siklus II adalah: 80

3) Modus yang diperoleh adalah75

4) Banyak kelas (K)

$$
\begin{aligned}
& =1+3,3 \times \log (\mathrm{N}) \\
& =1+3,3 \times \log 27 \\
& =1+3,3 \times 1,43 \\
& =1+4,72=5,72=6
\end{aligned}
$$

$$
\text { (dibulatkan) }
$$

5) Rentang kelas (r)

$$
\begin{aligned}
& =\text { skor maksimum }- \text { skor } \\
& \text { minimum } \\
& =95-60=35
\end{aligned}
$$

6) Panjang kelas interval (i) $=\frac{r}{K}=$ $\frac{35}{6}=5,83=6($ dibulatkan $)$

Adapun tabel persiapan penyajian grafik sebagai berikut

Tabel 03. Data Kelas Interval Siklus II

\begin{tabular}{|c|c|c|c|c|}
\hline $\begin{array}{c}\text { No } \\
\text { Urut }\end{array}$ & Interval & $\begin{array}{c}\text { Nilai } \\
\text { Tengah }\end{array}$ & $\begin{array}{c}\text { Frekuensi } \\
\text { Absolut }\end{array}$ & $\begin{array}{c}\text { Frekuensi } \\
\text { Relatif }\end{array}$ \\
\hline 1 & $60-65$ & 62,5 & 1 & $3,70 \%$ \\
\hline 2 & $66-71$ & 68,5 & 1 & $3,70 \%$ \\
\hline
\end{tabular}




\begin{tabular}{|c|c|c|c|c|}
\hline 3 & $72-77$ & 74,5 & 7 & $25,93 \%$ \\
\hline 4 & $78-83$ & 80,5 & 5 & $18,52 \%$ \\
\hline 5 & $84-89$ & 86,5 & 3 & $11,11 \%$ \\
\hline 6 & $90-95$ & 92,5 & 10 & $37,04 \%$ \\
\hline \multicolumn{3}{|c|}{ Total } & $\mathbf{2 7}$ & $\mathbf{1 0 0 \%}$ \\
\hline
\end{tabular}

7) Penyajian dalam bentuk grafik/histogram

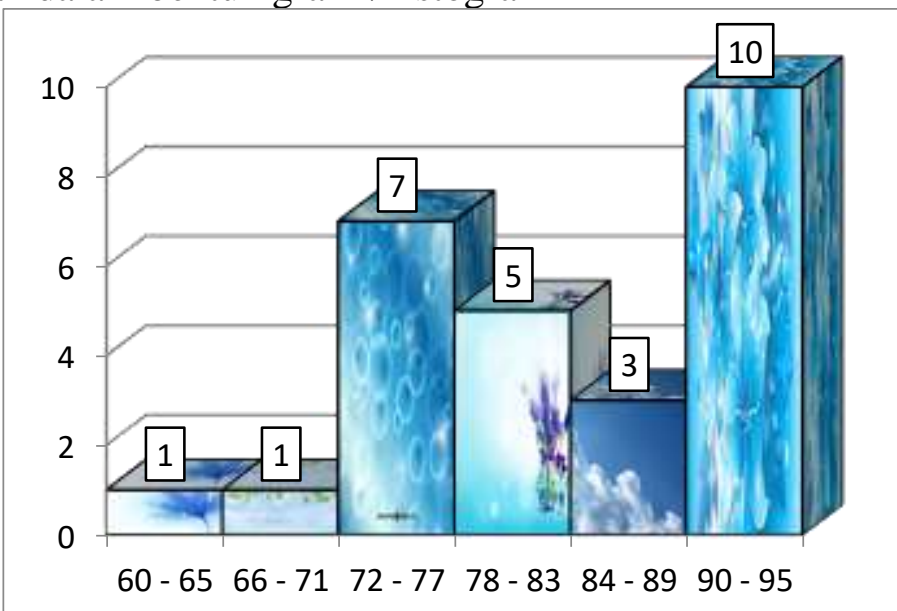

Gambar 03. Histogram Prestasi BelajarPKn Pada Siswa Kelas VI Semester I SD Negeri 2 Ubung Tahun Pelajaran 2016/2017 setelah Diterapkan Model Pembelajaran Kooperatif Student Team Achievement Division (STAD) Siklus II 


\section{B. Pembahasan}

Pada kegiatan awal diketahui nilai ratarata peserta didik sebesar 61,85. Hasil tersebut jauh di bawah KKM mata pelajaran PKn di kelas VISemester I SD Negeri 2 Ubung Tahun Pelajaran 2016/2017 yakni sebesar 75 poin.Ketidakberhasilan tersebut dikarenakan rendahnya kecakapan sosial siswa. Ketika siswa diminta mengerjakan tugas secara individu, siswa tidak merasakan kesulitan berarti meskipun nilai yang diperolehnya tergolong pas-pasan. Namun ketika siswa diminta mengejakan tugas secara berkelompok, banyak siswa yang hanya membebankan tugas pada siswa yang dianggap pintar saja, dan siswa yang pintar tersebut cenderung asal-asalan dalam bekerja karena merasa tidak dibantu oleh teman sekelompoknya. Hal ini sangat berdampak buruk kepada nilai prestasi belajar siswa.

Berdasarkan pengetahuan dan pemahaman peneliti, untuk menanggulangi permasalahan yang terjadi, peneliti perlu melakukan penelitian tindakan kelas dengan cara menenerapkanModel Pembelajaran Kooperatif Student Team Achievement Division (STAD) untuk Meningkatkan Prestasi Belajar PKn Siswa Kelas VI Semester I SD Negeri 2 Ubung Tahun Pelajaran 2016/2017

Dengan pelaksanaan pembelajaran telah diperbaiki pada siklus I ternyata dari 30 Dengan pelaksanaan pembelajaran telah diperbaiki pada siklus I, ternyata dari 27 siswa yang diteliti perolehan nilai rataratanya belum dapat memenuhi target nilai KKM 75, nilai rata-rata siswa hanya mencapai 71,48. Sejalan dengan perolehan nilai rata-rata, data ketuntasan belajar juga belum dapat memenuhi harapan. Persentase ketuntasan belajar baru mencapai 55,56 \% atau 12 siswa dari 27 total siswa, sedangkanindikator persentase ketuntasan belajar minimal sebanyak $85 \%$. Hasil tersebut menunjukan bahwa kemampuan sebagian besar siswa masih di bawah tuntutan indikator keberhasilan.

Setelah dilakukan refleksi dan penilaian, pada siklus I terdapat beberapa kekurangan yakni, 1) pembelajaran menggunakan model ini membutuhkan waktu yang relatif lama, 2) guru belum mampu menjadi fasilitator, mediator, motivator dan evaluator dengan baik

Selanjutnya peneliti telah berupaya secara maksimal pada siklus II. Berdasarkan pengalaman pada siklus I, dilakukan beberapa pembaruan pada persiapan dan pelaksanaan siklus II seperti, 1) meminimalisir penggunaan waktu dengan menyediakan lembar kegiatan siswa (LKS) sehingga siswa dapat bekerja secara efektif dan efisien, 2) meningkatkan mutu guru oleh pemerintah seperti mengadakan kegiatankegiatan akademik yang bersifat wajib dan tidak membebankan biaya kepada guru serta melakukan pengawasan rutin secara insindental, 3)pembentukan kelompok dan penataan ruang kelas sesuai kelompok yang ada dilakukan sebelum kegiatan pembelajaran dilaksanakan.

Pelaksanaan yang sudah maksimal pada siklus II ini,ternyata efektif untuk meningkatkan prestasi belajar siswa. Hal ini dapat dibuktikan dengan tercapainya seluruh indikator keberhasilan. Tuntutan indikator keberhasilan penelitian yang dicanangkan yaitu perolehan nilai rata-rata sebesar 75 sudah dapat dilampaui pada siklus ke II 
Jurnal Satyagraha, Vol. 02, No. 02, Agustus 2019 - Januari 2020 ISSN :2620-6358

dengan memperoleh nilai rata-rata sebesar 82,78. Hal yang sama terjadi pula pada indikator keberhasilan pada persentase ketuntasan belajar yakni sebesar $85 \%$ sudah dapat dilampaui dengan perolehan ketunatasan belajar pada siklus II sebesar 92,59\%. Hal ini menunjukan penelitian dicukupkan samapai siklus II

\section{Simpulan dan Saran}

Simpulan yang dapat diambil dalam penelitian tindakan kelas ini adalahmodel Pembelajaran Kooperatif Student team Achievement division (STAD) yang optimal, dapat meningkatkan prestasi belajar PKn Pada Siswa Kelas VI Semester I SD Negeri 2 Ubung tahun pelajaran 2016/2017.

Berdasarkan kesimpulan di atas dapat disampikan saran yaitu 1) Kepada temanteman guru dan pengawas sekolah disarankan untuk mencermati hasil-hasil penelitian ini dan apabila dimungkinkan agar diupayakan dalam penerapan selanjutnya di tempat pembinaan masing-masing; 2) Disarankan kepada kepala-kepala sekolah agar berkenan membaca secara teliti penelitian ini dan apabila sesuai dengan alur dalam melakukan pembinaan, agar dapat diteruskan untuk peningkatan mutu pendidikan; 3) Disarankan pada peneliti lain untuk meneliti hal yang sama untuk dapat memberi masukan, pembenaran, kritik, saran-saran perbaikan dan juga untuk memverifikasi hasil penelitian ini.

\section{Daftar Pustaka}

Basrowi dan Sukidin. 2002. Metode Penelitian Kualitatif Perspektif Mikro. Surabaya. Insan Cendikia.
Rasmini Ni Luh, 2010. Pengaruh Model Pembelajaran kooperatif STAD (Tipe Student Teams Achievement Divisions) dan Kemampuan Abstraksi Terhadap Hasil Belajar PKn Siswa SMP Wisata Sanur Denpasar (Tesis) ( tidak diterbitkan). Singaraja UNDIKSHA

Slavin, Robert E.1995. Cooperative Learning Theory, Research and Parctice Massachusett, USA: Allymad \& Bacon

Sumadi Suryabrata. 2006. Psikologi Pendidikan. Jakarta: PT Raja Grafindo Persada

Wuryandani, $\quad$ Wuri. 2011. Pembelajaran PKn di Sekolah Dasar. Yogyakarta: Nuha Litera 